\title{
Elevated preeclampsia rates during winter with reduced sunlight dependent vitamin $\mathrm{D}$ production
}

\author{
Jain Madhu ${ }^{1 *}$, Kapry Sweety ${ }^{1}$, Jain Shuchi ${ }^{1}$, Singh SK $^{2}$ and Singh TB $^{3}$ \\ ${ }^{1}$ Department of Obstetrics and Gynaecology, IMS, B.HU, Varanasi, U.P., India \\ ${ }^{2}$ Department of Endocrinology and Metabolism, IMS, B.H.U., India \\ ${ }^{3}$ Department of Biostatistics, IMS, B.H.U., India
}

\begin{abstract}
Title: Preeclampsia rates are elevated during winter month when sunlight dependent vitamin D production is reduced. Aim: To assess maternal vitamin D deficiency in early pregnancy and risk of preeclampsia.

Settings and Design: Nested case control study. Two maternal blood sample, one at $<20$ wks and other at term along with cord blood at delivery were taken. Patients were classified into preeclampsia $(n=57)$ and control group $(n=178)$ after abstracting past medical records at delivery. Methods and Material: Vitamin D was estimated by 25-Hydroxyvitamin D 125 I RIA Kit and categorized according to ACOG (2011) criteria. Statistical analysis used: Pearson $\chi^{2}$, ANOVA and logistic regression were used. Linear correlation and regression coefficient was used between maternal $25(\mathrm{OH}) \mathrm{D}$ at $<20$ wks and term and cord serum $25(\mathrm{OH}) \mathrm{D}$ levels. Results: serum $25(\mathrm{OH}) \mathrm{D}$ concentrations in early pregnancy were $56 \%$ significantly lower in women who subsequently developed preeclampsia compared with controls (mean, $9.79 \pm$ $4.09 \mathrm{ng} / \mathrm{ml}, 95 \% \mathrm{CI}, 8.71-10.88 \mathrm{ng} / \mathrm{ml}$, vs. $22.26 \pm 15.28 \mathrm{ng} / \mathrm{ml}$ and, $95 \% \mathrm{CI}, 20.0-24.52 \mathrm{ng} / \mathrm{ml}$; P<0.001) independent of age, BMI, calcium intake, socioeconomic status, periconceptional multivitamin use, residence. There was 17 times increased risk of preeclampsia in vitamin D deficient mothers compared to controls at early pregnancy and at term. $(\mathrm{P}<0.001 ; \mathrm{rr}=17.93)$. Newborns of preeclamptic mothers were more than three times as likely as newborns of controls to have hypovitaminosis $\mathrm{D}$ (relative risk 3.55). Conclusions: Maternal vitamin $\mathrm{D}$ deficiency is highly prevalent in early pregnancy and is an independent risk factor for preeclampsia.
\end{abstract}

\section{Introduction}

Preeclampsia affects approximately 3-7\% of first pregnancies. Preeclampsia rates are elevated during winter month when sunlight dependent $25(\mathrm{OH}) \mathrm{D}$ production is reduced $[1,2]$. A number of factors including vitamin $\mathrm{D}$ inadequacy have been proposed in the etiology of preeclampsia [3]. Preeclampsia is associated with low circulating level of IGF -1 and $1,25(\mathrm{OH}) 2 \mathrm{D}$. It has been seen that in vitro IGF-1 increases $1,25(\mathrm{OH}) 2 \mathrm{D}$ production by primary human syncytiotrophoblast from placenta from normal pregnancies but not from preeclampsia [4]. So far no study has explored the role of vitamin D deficiency in preeclampsia in India. The present study was under taken to assess maternal vitamin $\mathrm{D}$ deficiency in early pregnancy and risk of preeclampsia.

\section{Subjects and methods}

A nested case control study was conducted on total number of 500 patients enrolled from September 2011 to May 2013 attending antenatal clinic who initiated prenatal care before 20 weeks gestation and were younger than 45 years of age. The patients with history of diabetes mellitus, chronic hypertension, chronic renal disease, previous history of vitamin D intake, patients with fat malabsorption, with gastric bypass surgery, diagnosis of cancer, lupus, hepatitis, multiple intrauterine pregnancy, women taking anticonvulsant drugs were excluded. Participants completed a schedule administered by a interviewer at enrolment after written informed consent The schedule was used to gather information on socio-demographic, anthropomorphic, behavioral characteristics, reproductive and medical histories ,socioeconomic status(modified kuppuswami index) Women were enquired about physical activity from 10 am to $2 \mathrm{pm}$ in sun in the year before the index pregnancy or during pregnancy and to rate the usual intensity of this activity as low $(<3 \mathrm{hrs})$ or high $(\geq 3 \mathrm{hrs})$ according to duration of sunlight exposure. In Our study population only face and arms were exposed to sunlight. For Pre pregnancy body mass index (BMI) in our study most of patients belonged to low socioeconomic background and didn't have record of weight in pre pregnancy period. So in many cases weight was taken at first visit and was adjusted for pre pregnancy weight. Season of sample collection was defined as winter (December to February), spring (March to May), summer (June to August), and autumn (September to November). A history of maternal education ( $<12$ or $\geq 12 \mathrm{std}$ ), and Multivitamin use at least once per week in the periconceptional period (defined as the 3 months before and 3 months after conception) were also taken.

At the same time blood was collected aseptically by venipuncture in a $5 \mathrm{ml}$ glass tube. Serum samples were stored at $-20^{\circ} \mathrm{C}$ or lower for estimation of 25 hydroxyvitamin $\mathrm{D}[(25(\mathrm{OH}) \mathrm{D}]$ at later stage. Subjects were followed in second and third trimester and at delivery maternal

Correspondence to: Jain Madhu, M.D, Department of Obstetrics and Gynaecology, IMS, B.HU., Varanasi, U.P., India, Tel: 09415302988; E-mail: drmadhujainbhu@gmail.com

Received: September 01, 2015; Accepted: September 19, 2015; Published: September 22, 2015 
blood and cord blood sample were collected. After delivery, Medical records were abstracted to ascertain blood pressures and urinary protein measurements throughout gestation, use of antihypertensive medications, ante partum and delivery events, family history of DM and neonatal outcomes. At this point patients were categorised into preeclampsia group and control group. Among total of 500 women enrolled in the study, 385 returned for follow up at first visit, 110 were subsequently lost in second and third trimester follow up, and 20 had delivery at other hospital or at home.11 samples were found to be contaminated, 9 samples were hemolysed. Only that subjects were taken in study who had at least one sample at less than $20 \mathrm{wks}$, one term sample and cord blood sample. So only 235 had proper follow up till term delivery. 57 women out of them were identified as preeclampsia [5] and 178 were taken as control. All had 3 blood samples i.e. sample at $<20$ wks gestation, term, and cord blood. Preeclampsia group was further divided into severe and mild preeclampsia [6,7]. There were 29 cases of severe preeclampsia and 28 cases of mild preeclampsia. Mean gestational age of blood sample collection at $<20 \mathrm{wk}$ in preeclampsia and control group were $16 \pm 3.2$ wks and $16 \pm 2.2$ wks respectively. At term gestation, same values were $36.6 \pm 2.4$ wks and $37 \pm 2.4$ wks respectively.

Preeclampsia was defined as gestational hypertension and proteinuriaand return of all abnormalities to normal by $12 \mathrm{wk}$ postpartum [5]. Gestational hypertension was defined as systolic blood pressure persistently $140 \mathrm{~mm} \mathrm{Hg}$ or higher and/or diastolic blood pressure persistently $90 \mathrm{~mm} \mathrm{Hg}$ or higher for the first time after 20 wk gestation. We determined blood pressure as the average of the last five pressuresobtained after hospital admission for delivery before medications orclinical perturbations that would alter blood pressure. Proteinuria wasdefined as the excretion of more than $300 \mathrm{mg}$ protein in $24 \mathrm{~h}$, a random sample of $2+$ protein, a catheterized sample of $1+$ protein, or a protein/creatinine ratio more than 0.3 . [5] The study was approved by medical ethical committee.

Banked serum samples were taken out and subjected to 25(OH) D 125 I RIA Kit estimation. Serum 25-(OH) D concentrations were measured using DiaSorin enzyme immunoassay reagents and procedures (Metametrix, Norcross, GA) and categorized according to ACOG (2011) criteria: vitamin D sufficiency ( $\geq 30 \mathrm{ng} / \mathrm{ml}$ ), insufficiency $(20-29 \mathrm{ng} / \mathrm{ml})$ and deficiency $(<20 \mathrm{ng} / \mathrm{ml})$ [8]. However in neonates, Vitamin D status was classified according to Drug and Therapeutics Committee of the Lawson Wilkins Pediatric Endocrine Society recommendation: vitamin D(25-OH-D )20-100 ng/ml: sufficiency; $15-$ $20 \mathrm{ng} / \mathrm{ml}$ : insufficiency, $5-15 \mathrm{ng} / \mathrm{ml}$ : deficiency and $<5 \mathrm{ng} / \mathrm{ml}$ : severe deficiency [9-11].

Statistical analysis was done using SPSS 16 . We used Pearson $\chi^{2}$ statistics to compare proportions of women or neonates with vitamin $\mathrm{D}$ deficiency by case status. One way analysis of variance was used to compare the significant difference in mean among the group and if this test resulted significant then multiple range test (SNK) was used to find out pair wise difference in means .linear correlation and regression coefficient was used between maternal $25(\mathrm{OH}) \mathrm{D}$ at $<20$ wks and term and cord blood 25(OH)D levels. Binary logistic regression was used to assess the independent effect of maternal early-pregnancy $25(\mathrm{OH})$ D concentrations on the risk of GDM. The sample size was calculated assuming the prevalence of subjects of $75 \%$; absolute error $6 \%$ at $5 \%$ level of significance at two tailed tests, the sample size came out to be 200. Taking dropout of $60 \%, 500$ cases were registered for the study.

\section{Results}

We have found high incidence of vitamin D deficiency at early pregnancy and at term i.e. $76.1 \%$ (179 out of 235 ) vs. $77.2 \%$ (181 out of 235) respectively. Preeclamptic cases were mostly in age group of 25-29 yrs, overweight, had low level of physical activity in sun and less use of periconceptional multi vitamin use from beginning of the pregnancy. Most of the preeclampsia cases occured in winter season (Table 1). Low physical activity in sun vegetarian diet, winter season were important risk factors (combined likelihood ratio $(L R)=52.436$, $\left.\mathrm{R}^{2}=0.881\right)$. Including these risk factors $97 \%$ of $25(\mathrm{OH}) \mathrm{D}$ concentrations were correctly identified. Inclusion of other risk factors like BMI ,socioeconomic status, residence, age, periconceptional multivitamin use etc. hardly changed overall $25(\mathrm{OH}) \mathrm{D}$ concentration in cohort study. In our study we found out that vitamin D deficiency in early pregnancy i.e. at less than 20wk gestation was more prevalent among women who later developed preeclampsia than among women who did not develop preeclampsia ( $100 \%$ vs. $68.5 \%$ respectively, Table 2$)$.

Early-pregnancy maternal $25(\mathrm{OH}) \mathrm{D}$ concentration less than $20 \mathrm{ng} / \mathrm{ml}$ was significantly associated with risk of preeclampsia $(\mathrm{p}<0.001)$, independent of age, pre pregnancy BMI, education, gravida, socioeconomic status, urban or rural back ground, religion, calcium intake (Table 2 and 3). Serum 25(OH)D concentrations in early pregnancy were $56 \%$ lower in women who subsequently developed preeclampsia compared with non preeclamptic controls (mean, $9.79 \pm 4.09 \mathrm{ng} / \mathrm{ml}$, and 95\% confidence interval (CI), 8.71-10.88 ng/ $\mathrm{ml}$, vs. $22.26 \pm 15.28 \mathrm{ng} / \mathrm{ml}$ and $95 \%$ CI $20.0-24.52 \mathrm{ng} / \mathrm{ml} ; P<0.001)$, independent of BMI, age, education, gravida, socioeconomic status, urban or rural back ground, religion and calcium intake (Table 2,3 and Figure 1).

At term, maternal 25(OH) D concentrations remained $60 \%$ lower in women with overt preeclampsia compared with non-preeclamptic controls (adjusted mean, $8.43 \pm 3.95 \mathrm{ng} / \mathrm{ml}$, and 95\% CI, $7.38-9.48$ $\mathrm{ng} / \mathrm{ml}$, vs., $21.33 \pm 14.40 \mathrm{ng} / \mathrm{ml}$ and $19.20-23.46 \mathrm{ng} / \mathrm{ml} ; P<0.001$ ) independent of pre pregnancy BMI, age, season, gravida, socioeconomic status, urban or rural back ground, religion and calcium intake. (Table 2,3 and Figure 2)

This study showed that there was further decrease in $25(\mathrm{OH}) \mathrm{D}$ concentration with increasing gestational age, which may be due to a disturbance in local $1 \alpha$-hydroxylation within the placenta/deciduas and active transplacental transport of $\mathrm{Ca}$ to the developing fetus with advancing gestational age $[12,13]$. August $e t$ al. also reported reduction in the levels of circulating $1,25(\mathrm{OH}) 2 \mathrm{D}$ in preeclamptic patients compared with normotensive or chronically hypertensive pregnant controls [4]. There was 17 times increase risk of preeclampsia in vitamin $\mathrm{D}$ deficient mothers than non deficient mothers (Relative risk $=17.93$ (95\% CI=3.886-102.52) (Table 2). Overall, the findings suggested that low 25-hydroxy vitamin D levels in early pregnancy was strong and independent risk factor for preeclampsia.

We also found $25(\mathrm{OH}) \mathrm{D}$ level at $<20 \mathrm{wk}$ gestationwas negatively correlated with systolic blood pressure $(\mathrm{r}=-0.473, \mathrm{p}<0.001)$ and diastolic blood pressure $(\mathrm{r}=-0.469, \mathrm{p}<0.001)$ which was significant (Figure 4 and 5). In addition, severe Preeclampsia group was more significantly associated with vitamin $\mathrm{D}$ deficiency $(\mathrm{r}=-0.467, \mathrm{p}=.014)$ compared to mild Preeclampsia $(r=-0.340, p=0.004)$ at early pregnancy. Similarly at term gestation, severe Preeclampsia $(\mathrm{r}=-0.472, \mathrm{p}=.028)$ was more correlated with vitamin D deficiency than mild Preeclampsia $(r=-0.359$, $\mathrm{p}=0.003$ ). Also there was more correlation in severe Preeclampsia group than mild Preeclampsia patients in neonatal cord blood serum $25(\mathrm{OH})$ 
Table 1. Maternal characteristics.

\begin{tabular}{|c|c|c|c|c|c|}
\hline Maternal Characteristics & & $\begin{array}{l}\text { Preeclampsia } \\
\text { cases }(\mathbf{N}=57)\end{array}$ & $\begin{array}{r}\text { Controls } \\
(N=178)\end{array}$ & $\chi^{2}$ & P value \\
\hline \multirow[t]{3}{*}{ Age (years) } & $<25$ & $17(29.8 \%)$ & $86(48.3 \%)$ & & \\
\hline & $26-29$ & $21(36.8 \%)$ & $48(27 \%)$ & & \\
\hline & $\geq 30$ & $19(33.4 \%)$ & $44(24.7 \%)$ & 5.997 & 0.05 \\
\hline \multirow{4}{*}{$\begin{array}{l}\text { Pre pregnancy } \\
\mathrm{BMI}\left(\mathrm{kg} / \mathrm{m}^{2}\right)\end{array}$} & $<18.5$ & $1(1.8 \%)$ & $4(2.2 \%)$ & & \\
\hline & $18.5-24.9$ & $22(38.6 \%)$ & $116(65.2 \%)$ & & \\
\hline & $25-29.9$ & $32(56.1 \%)$ & $58(32.6 \%)$ & 17.74 & $<0.001$ \\
\hline & $\geq 30$ & $2(3.5 \%)$ & 0 & & \\
\hline \multirow[t]{2}{*}{ Gravida } & primi & $42(73.7 \%)$ & $68(38.2 \%)$ & 20.43 & $<0.001$ \\
\hline & multi & $15(26.3 \%)$ & $110(61.8 \%)$ & & \\
\hline \multirow[t]{2}{*}{ Education standard } & $<12$ & $15(26.3 \%)$ & $52(29.2 \%)$ & 0.001 & 0.98 \\
\hline & $\geq 12$ & $42(73.7 \%)$ & $136(70.8 \%)$ & & \\
\hline \multirow{2}{*}{$\begin{array}{l}\text { Periconceptional } \\
\text { Multivitamin use }\end{array}$} & No & $8(14 \%)$ & $49(27.5 \%)$ & & \\
\hline & yes & $49(86 \%)$ & $129(72.5 \%)$ & 4.27 & 0.039 \\
\hline \multirow[t]{2}{*}{ Calcium intake } & No & $8(14 \%)$ & $16(9 \%)$ & & \\
\hline & yes & $49(86 \%)$ & $162(91 \%)$ & 1.199 & 0.27 \\
\hline \multirow[t]{2}{*}{ Physical activity in sun } & High ( $\geq 3$ hrs) & 0 & $52(29.2 \%)$ & & \\
\hline & Low $(<3 \mathrm{hrs})$ & $57(100 \%)$ & $126(70.8 \%)$ & 21.38 & $<0.001$ \\
\hline \multirow[t]{2}{*}{ Diet } & Non veg & $4(7 \%)$ & $56(31.5 \%)$ & & \\
\hline & Veg & $53(93 \%)$ & $122(68.5 \%)$ & 13.56 & $<0.001$ \\
\hline \multirow[t]{2}{*}{ Smoking } & No & $56(98.2 \%)$ & $167(93.8 \%)$ & & \\
\hline & Yes & $1(1.8 \%)$ & $11(6.2 \%)$ & 1.74 & 0.187 \\
\hline \multirow[t]{2}{*}{ Residence } & Urban & $40(70.2 \%)$ & $107(60.1 \%)$ & 1.86 & 0.172 \\
\hline & Rural & $17(29.8 \%)$ & $71(39.9 \%)$ & & \\
\hline \multirow[t]{2}{*}{ Socioeconomic status } & High & $39(68.4 \%)$ & $107(60.1 \%)$ & 1.267 & 0.5 \\
\hline & Low & $18(31.6 \%)$ & $71(39.9 \%)$ & & \\
\hline \multirow[t]{4}{*}{ Season } & Summer & $8(14.0 \%)$ & $25(14 \%)$ & & \\
\hline & Autumn & 0 & $22(12.4 \%)$ & & \\
\hline & Spring & $13(22.8 \%)$ & $71(39.9 \%)$ & & \\
\hline & Winter & $36(63.2 \%)$ & $60(33.7 \%)$ & 19.73 & $<0.001$ \\
\hline
\end{tabular}

Table 2. Association between preeclampsia diagnosis and maternal $25(\mathrm{OH})$ vitamin D status at $<20$ wks gestation and term gestation.

\begin{tabular}{|c|c|c|c|c|}
\hline \multirow{2}{*}{$25(\mathrm{OH}) D$ values $(\mathrm{ng} / \mathrm{ml})$} & \multicolumn{2}{|c|}{ gestational age $<20$ wks } & \multicolumn{2}{|c|}{ Term gestational age } \\
\hline & Preeclampsia Cases $(n=57)$ & Controls $(n=178)$ & Preeclampsia Cases $(n=57)$ & Controls $(n=178)$ \\
\hline$<20$ (deficient) & $57(100 \%)$ & $122(68.5 \%)$ & $56(98.2 \%)$ & $125(70.2 \%)$ \\
\hline 20-29 (insufficient) & 0 & $19(10.7 \%)$ & $1(1.8 \%)$ & $17(9.6 \%)$ \\
\hline$>30$ (normal) & 0 & $37(20.8 \%)$ & 0 & $36(20.2 \%)$ \\
\hline
\end{tabular}

*20 wks: $\chi^{2}=23.543 ; \mathrm{p}$-value $<0.001$

$\dagger$ Term: $\chi^{2}=19.355$; $p$-value $<0.001$, Relative risk=17.93 (95\% CI=3.886-102.52) deficient $v$ s. non-deficient

D level, $(\mathrm{r}=-0.524, \mathrm{p}=.005)$ vs. $(\mathrm{r}=-0.366, \mathrm{p}=0.002)$ respectively. This might be a contributory factor of high maternal mortality for severe preeclampsia in our country apart from racial disparity. Overall, there was good correlation between maternal term and cord serum $25(\mathrm{OH})$
$\mathrm{D}$ concentration in preeclamsia cases $(\mathrm{r}=0.876 ; P<0.001)$ (Figure 6$)$ and controls $(\mathrm{r}=0.868 ; P<0.001)$.

Among preeclampsia cases who were deficient in $25(\mathrm{OH}) \mathrm{D}$ concentration level, $87.7 \%$ of neonates had deficient cord blood of 
Table 3. Mean $25(\mathrm{OH}) \mathrm{D}$ level $(\mathrm{ng} / \mathrm{ml})$ in preeclampsia and control group at $<20$ wks gestation, at term and cord blood serum.

\begin{tabular}{|c|c|c|c|c|c|}
\hline \multirow{2}{*}{ Serum $25(\mathrm{OH})$ D level $(\mathrm{ng} / \mathrm{ml})$} & & \multirow{2}{*}{$\mathbf{N}$} & \multirow{2}{*}{ Mean \pm SD $(\mathrm{ng} / \mathrm{ml})$} & \multicolumn{2}{|c|}{ 95\% Confidence Interval for Mean } \\
\hline & & & & Lower Bound & Upper Bound \\
\hline \multirow[t]{2}{*}{$<20$ wks } & Preeclampsia & 57 & $9.79 \pm 4.09$ & 8.710 & 10.885 \\
\hline & Control & 178 & $22.26 \pm 15.28$ & 20.003 & 24.524 \\
\hline \multirow[t]{2}{*}{ Term } & Preeclampsia & 57 & $8.43 \pm 3.95$ & 7.384 & 9.484 \\
\hline & Control & 178 & $21.33 \pm 14.40$ & 19.201 & 23.462 \\
\hline \multirow[t]{2}{*}{ Cord Blood } & Preeclampsia & 57 & $8.80 \pm 8.29$ & 6.603 & 11.008 \\
\hline & Control & 178 & $20.10 \pm 13.44$ & 18.114 & 22.090 \\
\hline
\end{tabular}

Table 4. Association between preeclampsia diagnosis and neonatal vitamin D status.

\begin{tabular}{|l|c|c|c|}
\hline \multirow{2}{*}{ Cord serum 25 $\mathbf{( O H}) \mathbf{D}(\mathbf{n g} / \mathbf{m l})$} & \multicolumn{2}{|c|}{ Neonates of preeclamptic mothers } & \multicolumn{2}{c|}{ Neonates of non-preeclamptic Control } \\
\cline { 2 - 4 } & No. & No. & 107 \\
\hline$<15$ (deficient) & 50 & 87.7 & 60.1 \\
\hline $15-20$ (insufficient) & 4 & 7 & 35 \\
\hline $20-100$ (normal) & 3 & 5.3 & 36 \\
\hline Total & 57 & 100 & 19.6 \\
\hline
\end{tabular}

$\chi^{2}=19.200 ; \mathrm{p}$-value $<0.001$, relative risk $=3.55,95 \%$ CI $(1.77-7.47)$.

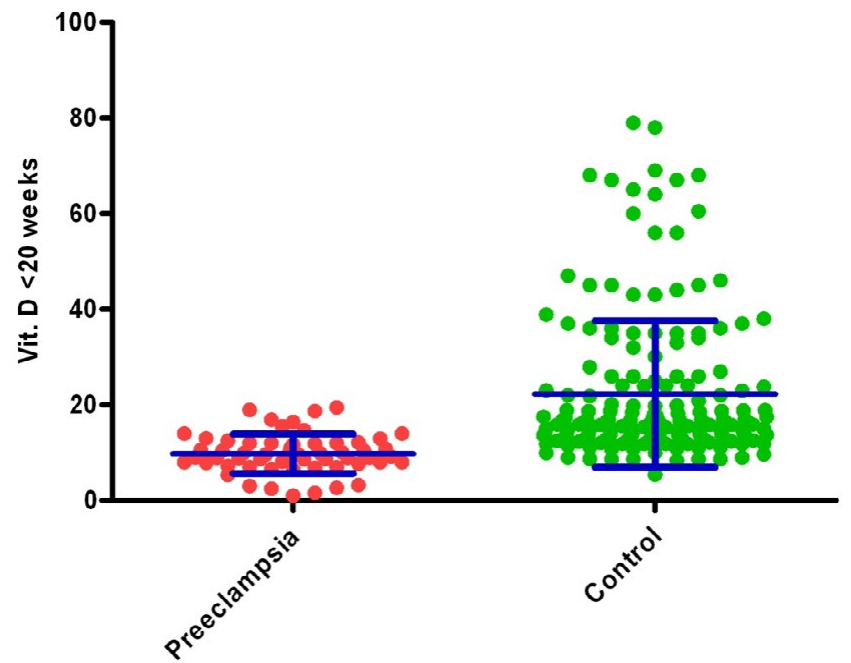

Figure 1. Maternal serum 25(OH)D concentrations at gestation age $<20 \mathrm{wks}$ in preeclampsia and controls.

25(OH)D concentration. $75.9 \%$ of Cord blood 25(OH)D Concentration can be correctly explained by known value of vitamin $\mathrm{D}$ at $<20 \mathrm{wks}$. Therefore, cord serum 25(OH)D concentrations were also significantly lower among neonates of preeclamptic mothers than among neonates of non-preeclamptic control mothers (adjusted mean, $8.80 \pm 8.29 \mathrm{ng} /$ $\mathrm{ml}$ and $95 \% \mathrm{CI}, 6.6-11.0 \mathrm{ng} / \mathrm{ml}, v s .21 .33 \pm 14.40$ and $95 \%$ CI $18.1-22.0$ $\mathrm{ng} / \mathrm{ml} ; P=0.001)$. Newborns of preeclamptic mothers were more than three times as likely as newborns of non-preeclamptic mothers to have hypovitaminosis D (relative risk: 3.55) (Table 3,4 and Figure 3).

\section{Discussion}

We have found a high incidence of vitamin D deficiency (76.1\%) in early pregnancy in a tropical country like India which has abundant sunlight for most of the year. This paradox can be explained due to

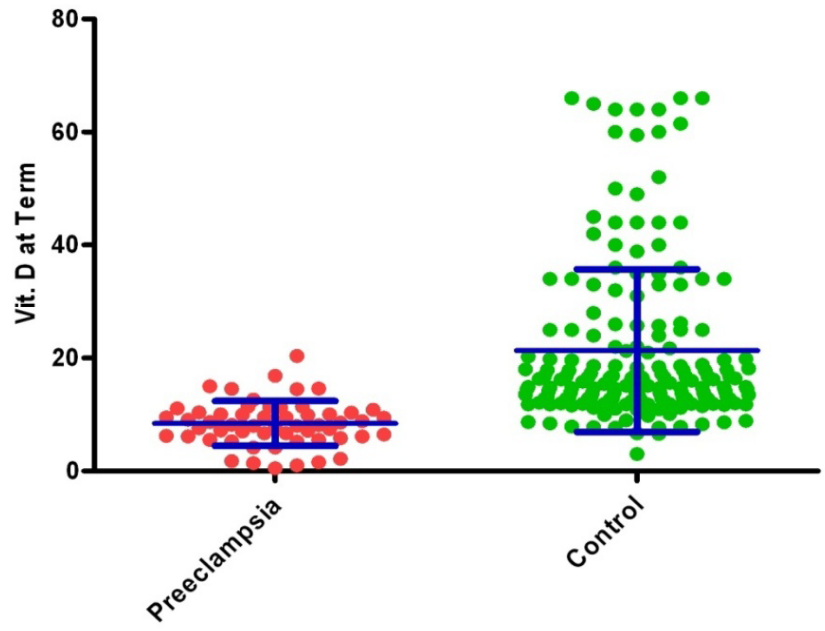

Figure 2. Maternal serum 25(OH)D concentrations at term (mean \pm SD) in preeclampsia and controls.

many prevalent social and cultural practices i.e. increased urbanisation, poor outdoor activity, greater pollution that preclude exposure of women to sunlight coupled with skin pigment melanin absorb UVB photons and reduces vitamin D synthesis by greater than $90 \%$.

Overall, our findings suggested that low serum 25(OH)D level in early pregnancy was strong and independent risk factor for preeclampsia.This can be explained by the fact that the active form of vitamin D, 1,25-dihydroxy vitamin D3, act as free hormone and regulates transcription and function of genes associated with placental invasion, normal implantation, and angiogenesis $[14,15]$. Furthermore, abnormal implantation is proposed to be mediated by an inappropriate immune response between mother and baby which is one of the etiological factor for preeclampsia This might be due to abnormal expression of 1 alfa hydroxylase, vitamin D activating enzyme in 


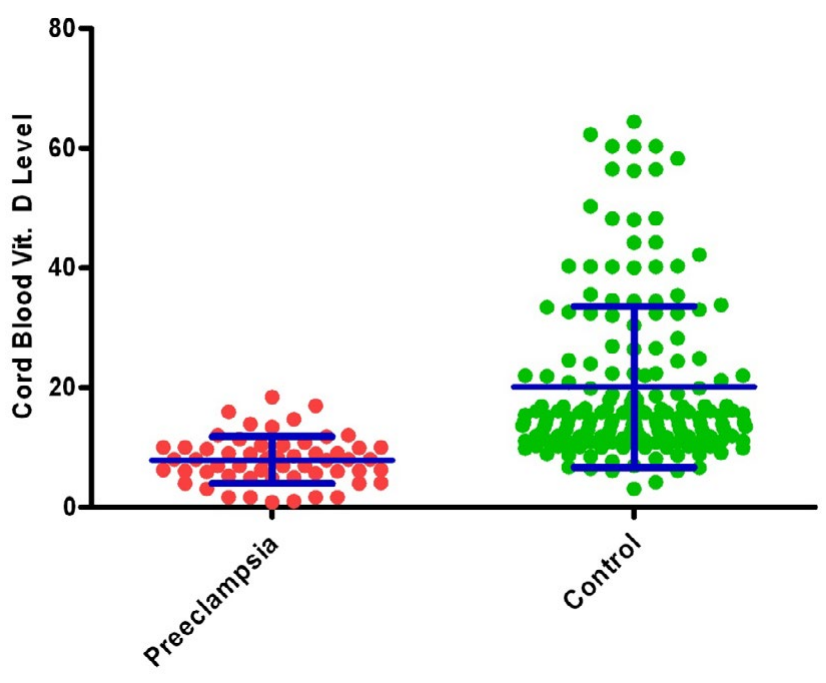

Figure 3. neonatal cord blood serum $25(\mathrm{OH}) \mathrm{D}$ concentrations among preeclampsia and controls (mean $\pm \mathrm{SD}$ ).

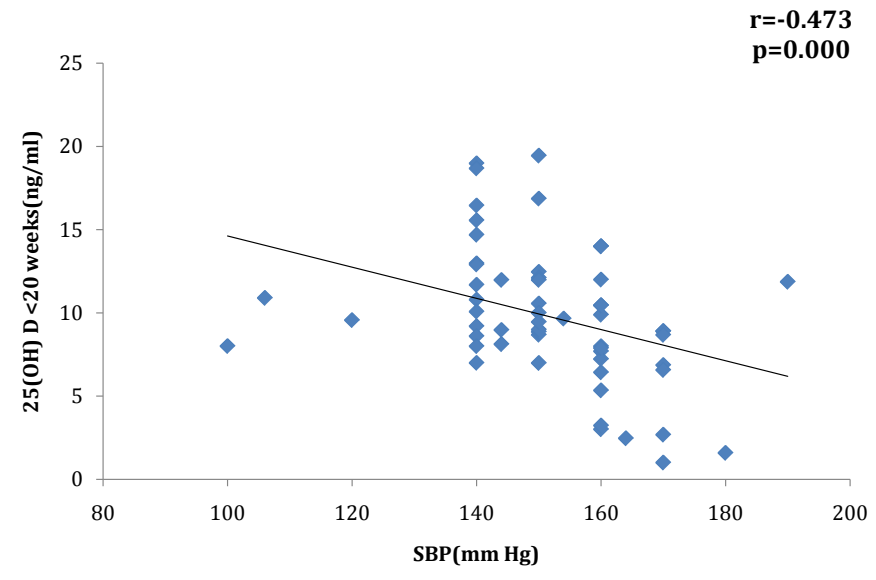

Figure 4. Correlation of $25(\mathrm{OH}) \mathrm{D}$ concentration $(\mathrm{ng} / \mathrm{ml})$ at $<20 \mathrm{wks}$ and systolic B.P.

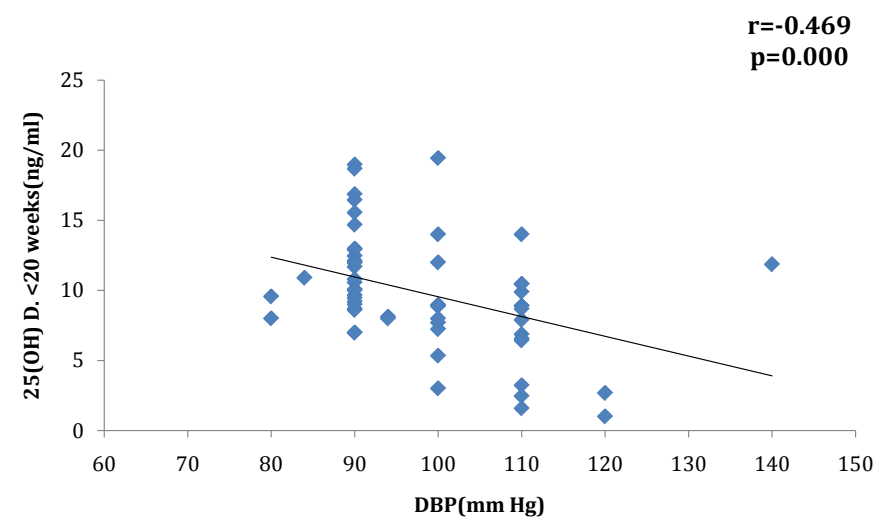

Figure 5. Correlation of $25(\mathrm{OH}) \mathrm{D}$ concentration $(\mathrm{ng} / \mathrm{ml})$ at $<20 \mathrm{wks}$ and diatolic B.P.

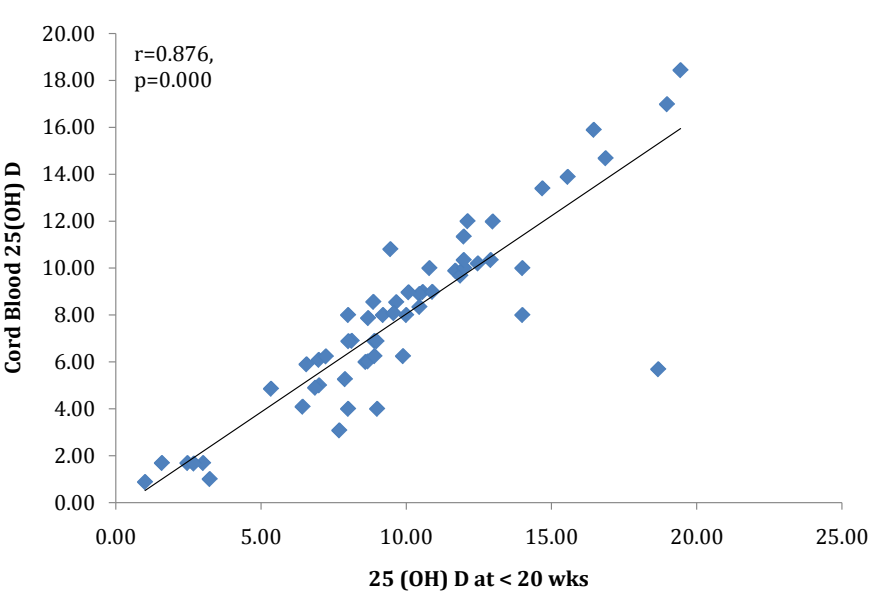

Figure 6. Correlation between $25(\mathrm{OH}) \mathrm{D}$ concentration at $<20$ wks and cord blood 25(OH)D level.

preeclamptic pregnancies revealing a potential role of $1,25(\mathrm{OH}) 2 \mathrm{D}$ as regulator of placentation.

The immunomodulatory properties of active hormonal metabolite $1,25(\mathrm{OH}) 2 \mathrm{D}$ plays an important role in the cross-talk between the mother and the fetus. Increased inflammatory response might be associated with vitamin D deficiency [16]. Also, vascular structure and compliance, elasticity, and intima media thickness are more favorable among women supplemented with vitamin D [17]. Vitamin $\mathrm{D}$ deficiency may also elevate blood pressure [18]. Finally, the 1,25-Dihydroxyvitamin D3 has been shown to regulate angiogenic processes through direct effects on renal vascular endothelial growth factor (VEGF) gene transcription [19] and proteinuria of preeclampsia is thought to be mediated by VEGF gene.

In our study, preeclampsia rates were elevated during winter month when sunlight dependent $25(\mathrm{OH}) \mathrm{D}$ production was reduced .There were $8(14 \%)$ cases of preeclampsia in summer, $13(22.8 \%)$ in spring and rest $36(63.2 \%)$ in winter. Whereas in control group same values were $25(14 \%)$ in summer, $22(12.4 \%)$ in autumn, $71(39.9 \%)$ in spring and rest $60(33.7 \%)$ in winter. The $p$ value $<0.001$ was significant for winter season. Seasonal variations in disease risk may be an indicator of an association between vitamin D status and the disease. Mostello et al. in 2002 reported preeclampsia is also more common in dark-skinned women (living in northern latitudes) [20], who typically have a higher prevalence of hypovitaminosis $\mathrm{D}$ than is found in comparable white women [21].

In Nordic countries, the incidence of preeclampsia peaks during winter and is the lowest in summer and early autumn, [1,2] a pattern that mirrors the trends in seasonal variation in vitamin $\mathrm{D}$ status [22]. In Nordic countries, the lack of UVB in sunlight between October and March means that there is no cutaneous vitamin D synthesis during those months [23]. A 2011, systematic review found that hypertension in pregnancy is more common in winter or rainy seasons when vitamin $\mathrm{D}$ deficiency is also higher [24].

Marwaha et al. reported that Serum 25(OH) D levels were significantly lower in winter in the second and third trimesters, while serum intact parathormone (iPTH) and alkaline phosphatase levels were significantly higher in winter in all three trimesters [25].

Similar to our study, Bodnar et al. found that maternal vitamin $\mathrm{D}$ deficiency may be an independent risk factor for preeclampsia. 
Adjusted serum 25(OH)D concentrations in early pregnancy were lower in women who subsequently developed preeclampsia compared with controls (geometric mean, $45.4 \mathrm{nmol} /$ liter, and $95 \%$ confidence interval (CI), 38.6-53.4 nmol/liter, vs. 53.1 and 47.1-59.9 nmol/liter; $P=0.01)$. There was a monotonic dose-response relation between serum $25(\mathrm{OH}) \mathrm{D}$ concentrations at less than $22 \mathrm{wk}$ and risk of preeclampsia. After confounder adjustment, a $50 \mathrm{nmol} /$ liter decline in $25(\mathrm{OH}) \mathrm{D}$ concentration doubled the risk of preeclampsia (adjusted odds ratio, 2.4; 95\% CI,1.1-5.4). Newborns of preeclamptic mothers were twice as likely as control newborns to have $25(\mathrm{OH}) \mathrm{D}$ less than $37.5 \mathrm{nmol} / \mathrm{liter}$ (adjusted odds ratio, 2.2; 95\% CI, 1.2-4.1) [26].

In a similar study by Baker et al. involving 43 cases and 198 matched controls, maternal 25(OH)D below $50 \mathrm{nmol} / \mathrm{l}$ at $15-20$ weeks gestation was associated with a five-fold increase in the odds of severe preeclampsia diagnosis after adjustment for multiple covariates (adjusted odds ratio (OR) 5.41, 95\% confidence interval (CI) 2.02 to 14.52) [27].

In contrast, two studies found no differences in first or second trimester $25(\mathrm{OH}) \mathrm{D}$ between women at low or high risk for preeclampsia who did or did not develop the disorder later in pregnancy $[28,29]$.

Marya et al. found out that after 8 to 10 weeks of supplementation of vitamin $\mathrm{D}$, blood pressure was significantly reduced in the treated group, and there was a suggestion that a smaller proportion of supplemented than control women developed preeclampsia $(6 \%$ compared with 9\%) [30].

The risk of preeclampsia was more than halved in women who had received vitamin $\mathrm{D}$ supplementation regularly during the first year of life [31].

Our results also highlight that neonates of preeclamptic mothers are at particularly high risk of vitamin D deficiency. However, these results are not unexpected. The fetus relies entirely on the vitamin $\mathrm{D}$ stores of the mother, so if the mother is deficient, so is the fetus [32,33]. Because early-life vitamin D deficiency has been associated with adverse health outcomes in offspring [34], neonates of preeclamptic mothers may be an easily identified group that needs a targeted intervention to improve vitamin D status from birth. Zeghoud et al., in stated that maternal vitamin D status correlates strongly with that of the newborn [35] and in a study on rickets of prematurity, preeclampsia was identified as a major risk factor [36].

\section{Conclusion}

Vitamin D deficiency has become a growing concern in our country. Vitamin D deficiency is common among pregnant women and has been associated with elevated risk for pregnancy complications such as preeclampsia and a number of serious short- and long term health problems in offspring [26,37]. Circulating vitamin D can be modified by food consumption (e.g. fatty fish), supplement use, and outdoor sun exposure. Optimizing the effective dose of vitamin D supplement continues to be a challenge. Our data raise the possibility that treating vitamin $\mathrm{D}$ deficiency in pregnancy, via supplementation or lifestyle measures, can contribute to the prevention of preeclampsia and promoting neonatal well-being.

\section{References}

1. Ros HS, Cnattingius S, Lipworth L (1998) Comparison of risk factors for preeclampsia and gestational hypertension in a population-based cohort study. Am J Epidemiol 147: 1062-1070. [Crossref]
2. Magnu P, Eskild A (2001) Seasonal variation in the occurrence of pre-eclampsia. BJOG 108: 116-119.

3. World health report 2005: make every mother and child count. Geneva: World Health Organization.

4. August P, Marcaccio B, Gertner JM, Druzin ML, Resnick LM, et al. (1992) Abnorma 1,25-dihydroxyvitamin D metabolism in preeclampsia. Am J Obstet Gynecol 166: 1295-1299. [Crossref]

5. [No authors listed] (2000) Report of the National High Blood Pressure Education Program Working Group on High Blood Pressure in Pregnancy. Am J Obstet Gynecol 183: S1-1S22. [Crossref]

6. Alexander JM, McIntire DD, Leveno KJ, Cunningham FG (2003) Magnesium sulphate for prevention of eclampsia in women with mild hypertension. Am J Obste Gynecol 189: $\mathrm{S} 89$

7. Lindheimer MD, Taler SJ, Cunningham FG (2008) Hypertension in pregnancy. $J \mathrm{Am}$ SocHypertens 2: 484-494. [Crossref]

8. Holick MF (2007) Vitamin D deficiency. N Engl J Med 357: 266-281. [Crossref]

9. Misra M, Pacaud D, Petryk A, Collett-Solberg PF, Kappy M; Drug and Therapeutics Committee of the Lawson Wilkins Pediatric Endocrine Society (2008) Vitamin D deficiency in children and its management. Paediatrics 122. [Crossref]

10. Munns C, Zacharin MR, Rodda CP, Batch JA, Morley R, et al. (2006) Prevention and treatment of infant and childhood vitamin D deficiency in Australia and New Zealand: a consensus statement. Med J Aust 185: 268-272. [Crossref]

11. Gordon CM, DePeter KC, Feldman HA, Grace E, Emans SJ (2004) Prevalence of vitamin D deficiency among healthy adolescents. Arch PediatrAdolesc Med 158: 531537. [Crossref]

12. Bourges H, Halhali A (1993) Hypothesis to explain the association between hypocalciuria and low circulating 1,25-dihydroxyvitamin D levels in preeclampsia. Med Hypotheses 41: 239-243. [Crossref]

13. Sealy EW, Wood RJ, Brown EM, Graves SW (1992) Lower serum ionized calcium and abnormal calciotropic hormone levels in preeclampsia. J Clin Endocrinol Metab 74: 1436-1440. [Crossref]

14. Evans KN, Bulmer JN, Kilby MD, Hewison M (2004) Vitamin D and placentaldecidual function. J Soc Gynecol Investig 11: 263-271. [Crossref]

15. Daftary GS, Taylor HS (2006) Endocrine regulation of HOX genes. Endocr Rev 27: 331-355. [Crossref]

16. Hewison M (1992) Vitamin D and the immune system. J Endocrinol 132: 173-175. [Crossref]

17. Braam LA, Hoeks AP, Brouns F, Hamulyák K, Gerichhausen MJ, et al. (2004) Beneficial effects of vitamins D and $\mathrm{K}$ on the elastic properties of the vessel wall in postmenopausal women: a follow-up study. Thromb Haemost 91: 373-380. [Crossref]

18. Li YC, Kong J, Wei M, Chen ZF, Liu SQ, et al. (2002) 1,25-Dihydroxyvitamin D(3) is a negative endocrine regulator of the renin-angiotensin system. J Clin Invest 110: 229-238. [Crossref]

19. Cardús A, Parisi E, Gallego C, Aldea M, Fernández E, et al. (2006) 1,25-Dihydroxyvitamin D3 stimulates vascular smooth muscle cell proliferation through a VEGF-mediated pathway. Kidney Int 69: 1377-1384. [Crossref]

20. Mostello D, Catlin TK, Roman L, Holcomb WL Jr, Leet T (2002) Preeclampsia in the parous woman: who is at risk? Am J Obstet Gynecol 187: 425-429. [Crossref]

21. Harris SS, Dawson-Hughes B (1998) Seasonal changes in plasma 25-hydroxyvitamin D concentrations of young American black and white women. Am J Clin Nutr 67: 1232-1236. [Crossref]

22. Tjellesen L, Christiansen C (1983) Vitamin D metabolites in normal subjects during one year. A longitudinal study. Scand J Clin Lab Invest 43: 85-89. [Crossref]

23. Webb AR, Kline L, Holick MF (1988) Influence of season and latitude on the cutaneous synthesis of vitamin D3: exposure to winter sunlight in Boston and Edmonton will no promote vitamin D3 synthesis in human skin. J Clin Endocrinol Metab 67: 373-378. [Crossref]

24. TePoel MR, Saftlas AF, Wallis AB (2011) Association of seasonality with hypertension in pregnancy: a systematic review. J Reprod Immunol 89: 140-152. [Crossref]

25. Marwaha RK, Tandon N, Chopra S, Agarwal N, Garg MK, et al. (2011) Vitamin D status in pregnant Indian women across trimesters and different seasons and its correlation with neonatal serum 25-hydroxyvitamin D levels. Br J Nutr 106: 1383-1389. [Crossref] 
26. Bodnar LM, Catov JM, Simhan HN, Holick MF, Powers RW, et al. (2007) Maternal vitamin D deficiency increases the risk of preeclampsia. J Clin Endocrinol Metab 92: 3517-3522. [Crossref]

27. Baker AM, Haeri S, Camargo CA Jr, Espinola JA, Stuebe AM (2010) A nested casecontrol study of midgestation vitamin D deficiency and risk of severe preeclampsia. $J$ Clin Endocrinol Metab 95: 5105-5109. [Crossref]

28. Powe CE, Seely EW, Rana S, Bhan I, Ecker J, et al. (2010) First trimester vitamin D, vitamin D binding protein, and subsequent preeclampsia. Hypertension 56: 758-763. [Crossref]

29. Shand AW, Nassar N, Von Dadelszen P, Innis SM, Green TJ (2010) Maternal vitamin $\mathrm{D}$ status in pregnancy and adverse pregnancy outcomes in a group at high risk for preeclampsia. BJOG 117: 1593-1598. [Crossref]

30. Marya RK, Rathee S, Manrow M (1987) Effect of calcium and vitamin D supplementation on toxaemia of pregnancy. Gynecol Obstet Invest 24: 38-42. [Crossref]

31. Hypponen E, Pouta A, Sovio U, et al (2004) Vitamin D supplementation in infancy and risk of pregnancyinduced hypertension: a birth cohort study. In: Rissanen $\mathrm{TH}$, Korhonen M, Happonen P, eds. Third Nordic Conference in Epidemiology. Kuopio, Finland: Kuopio University Publications: 61
32. Lee JM, Smith JR, Philipp BL, Chen TC, Mathieu J, et al. (2007) Vitamin D deficiency in a healthy group of mothers and newborn infants. ClinPediatr (Phila) 46: 42-44. [Crossref]

33. Hollis BW, Pittard WB 3rd (1984) Evaluation of the total fetomaternal vitamin D relationships at term: evidence for racial differences. J Clin Endocrinol Metab 59: 652-657. [Crossref]

34. McGrath J (2001) Does 'imprinting' with low prenatal vitamin D contribute to the risk of various adult disorders? Med Hypotheses 56: 367-371. [Crossref]

35. Zeghoud F, Vervel C, Guillozo H, Walrant-Debray O, Boutignon H, et al. (1997) Subclinical vitamin D deficiency in neonates: definition and response to vitamin D supplements. Am J Clin Nutr 65: 771-778. [Crossref]

36. Bosley AR, Verrier-Jones ER, Campbell MJ (1980) Aetiological factors in rickets of prematurity. Arch Dis Child 55: 683-686. [Crossref]

37. Dent CE, Gupta MM (1975) Plasma 25-hydroxyvitamin-D-levels during pregnancy in Caucasians and in vegetarian and non-vegetarian Asians. Lancet 2: 1057-1060. [Crossref]

Copyright: (2015 Madhu J. This is an open-access article distributed under the terms of the Creative Commons Attribution License, which permits unrestricted use, distribution, and reproduction in any medium, provided the original author and source are credited. 